\title{
Medical waste disposal at a hospital in Mpumalanga Province, South Africa: Implications for training of healthcare professionals
}

\author{
R R Makhura, MPH; S F Matlala, DLitt et Phil (Health Studies); M P Kekana, MPH \\ Department of Public Health, Faculty of Health Sciences, University of Limpopo, Sovenga, South Africa
}

Corresponding author: S F Matlala (france.matlala@ul.ac.za)

Background. Healthcare professionals (HCPs) produce various types of waste in the course of rendering healthcare services. Each classification of waste must be disposed of according to the prescribed guidelines. Incorrect disposal of waste may pose a danger to employees, patients and the environment. HCPs must have adequate knowledge of the disposal of medical waste.

Objectives. To determine the knowledge and practices of HCPs with regard to medical waste disposal at a hospital in Mpumalanga Province, South Africa.

Methods. A quantitative cross-sectional research approach was used. The study respondents included nurses, medical doctors, dental health staff and allied health staff. Data were collected through self-administered questionnaires and analysed using IBM SPSS version 22.0.

Results. A high proportion of HCPs did not have adequate knowledge regarding the disposal of medical waste, but nevertheless disposed of medical waste appropriately. While the knowledge and practices of HCPs with regard to medical waste disposal were not associated with age, gender or years of experience, there was an association between professional category and knowledge and practices.

Conclusions. Disposal of medical waste is the responsibility of all HCPs. All categories of HCPs should receive regular training to improve their knowledge regarding disposal of medical waste and to minimise the risks associated with improper waste management. This will further increase compliance with the guidelines on disposal of medical waste.

S Afr Med J 2016;106(11):1096-1102. DOI:10.7196/SAMJ.2016.v106i11.10689

Nurses, medical doctors, and dental and allied health staff are healthcare professionals (HCPs) who generate various types of hazardous hospital waste when they provide healthcare services and when they conduct research in hospitals, clinics, blood banks and blood collection services, mortuary and postmortem centres, laboratories and research institutes. ${ }^{[1,2]}$ Hospital waste is classified as medical waste, chemical waste, radioactive waste, cytotoxic waste, pharmaceutical waste and general waste. The focus of this article is on medical waste, which includes sharps, laboratory waste, human tissue and cadavers used for research purposes. Each waste category must be disposed of correctly according to specific guidelines to protect HCPs, ward cleaners, laundry workers and patients from needlestick injuries and biological hazards. ${ }^{[1,2]}$ An important first step in the correct disposal of medical waste is the separation of waste at the point of generation, followed by its disposal into colour-coded containers. Medical waste in these containers can then be disposed of through incineration, sterilisation, chemical disinfection or burial in a secured landfill. ${ }^{[3]}$ Sharps, which include hypodermic needles, saws, pipettes, scalpels, broken glass and blades, are disposed of through incineration, chemical disinfection and microwaving. Laboratory waste, which includes body fluids, human tissue and cultures, can be disposed of through incineration or chemical disinfection. Human tissue, body parts, fetuses and cadavers must be disposed of through incineration. ${ }^{[2]}$ It is essential that all medical waste is separated out at the point of generation, appropriately treated and correctly disposed of. ${ }^{[2]} \mathrm{HCPs}$ have a responsibility to protect the community and other workers by disposing of medical waste correctly.

Correct disposal of medical waste requires that HCPs have adequate knowledge of the various disposal methods. All HCPs in South Africa (SA) receive training on the correct disposal of medical waste at the medical, dental or nursing schools they attend in order to qualify. ${ }^{[4]}$ Hospital management, as the employer of these HCPs, has a responsibility to provide employees with continuing training in correct disposal methods. HCPs also have a responsibility to attend training provided by their employers. ${ }^{[5]}$ Training should include knowledge of occupational hazards, management of exposure to blood and body fluids, correct medical waste disposal procedures, prevention of injury and diseases that could result from handling medical waste, and management of needlestick injuries. ${ }^{[6]}$ Studies indicate that a number of HCPs in countries such as Ghana, India, Pakistan, Malaysia and SA have inadequate knowledge of the categories of medical waste, correct waste disposal procedures for each category, and the legislation governing medical waste disposal in their countries. ${ }^{[7,8]}$

Occupational health reports at a hospital in Mpumalanga Province, SA, showed an increase in the number of needlestick injuries among ward cleaners. Ward cleaners do not use needles and other sharps, so it was not expected that they would experience such injuries. Studies indicate that ward cleaners are injured by needles that HCPs have disposed of incorrectly. ${ }^{[2,9,10]}$

\section{Objective}

To determine the knowledge and practices of HCPs regarding medical waste disposal at the study hospital, and the association between demographic factors and knowledge and practice of HCPs.

\section{Methods}

The study used a quantitative cross-sectional research approach. A sample of 178 HCPs was selected from a population of 319 employees through a stratified random sampling technique, using professional categories as strata. Data were collected by means of a self-administered questionnaire, which included completion instructions (Appendix 1). 
The questionnaire was adapted from a study conducted in Yemen. ${ }^{[11]}$ It had the headings 'agree', 'disagree' and 'neutral'. Agreeing with a statement meant having adequate knowledge, disagreeing meant inadequate knowledge, and neutral meant that the respondent was unsure. Ethical approval was obtained from the University of Limpopo (ref. no. MREC/ HS/277/2014: PG), and participants gave informed consent to participate in the study. The Mpumalanga provincial Department of Health and the management of the hospital gave permission for data collection at the hospital. Data were analysed using SPSS version 22.0 (IBM, USA), with the assistance of a statistician, into descriptive statistics such as frequencies. The $\chi^{2}$ test was used to test associations between variables.

\section{Results}

\section{Sociodemographic information}

The sample consisted of 178 HCPs (150 nurses (84.3\%), 9 medical doctors (5.1\%), 3 dental staff (1.7\%) and 16 allied health staff $(9.0 \%))$. The majority of the respondents $(144,80.9 \%)$ were females. Most respondents $(68.5 \%)$ were aged $\geq 36$ years, with only $2.2 \%$ being 21 - 25 years old. With regard to years of experience as HCPs, $24.2 \%$ of the respondents had 0 - 5 years' experience, $20.8 \% 6$ - 10 years, $16.9 \% 11-15$ years, $14.0 \% 16-20$ years and $24.2 \%>20$ years. HCPs with 0 - 5 years of experience and those with $>20$ years represented the majority of the respondents, while those with $16-20$ years of experience made up the smallest group.

\section{Knowledge and disposal practices}

Table 1 indicates that $80(44.9 \%)$ of the HCPs reported having inadequate knowledge of the correct disposal of medical waste, 84 (47.2\%) reported having adequate knowledge, and 14 (7.9\%) were not sure about the adequacy of their knowledge. Table 1 further indicates the percentage distribution of HCPs according to disposal practice, with $32.0 \%$ reporting incorrect disposal practices, $61.8 \%$ reporting correct practices and $6.2 \%$ being unsure about the correctness of their disposal practices.

\section{Association between knowledge and medical waste disposal practices}

Of the respondents, $19.7 \%$ reported having inadequate knowledge of disposal practices but nevertheless employed correct disposal practices; a higher proportion (22.5\%) employed incorrect disposal practices and had inadequate knowledge of these practices. Nine percent of the respondents reported employing incorrect disposal practices despite having adequate knowledge of these practices, while a higher proportion $(36.0 \%)$ reported having adequate knowledge of disposal practices and also employing correct disposal practices. There was an association between knowledge and practice with respect to medical waste disposal ( $\chi^{2}$ test, $p=0.000$ ) (Table 2).

\section{Association between sociodemographic factors and knowledge and practice of medical waste disposal}

There was an association between professional category and both knowledge about the disposal of medical waste ( $\chi^{2}$ test, $p=0.003$ ) and practice of HCPs $\left(\chi^{2}\right.$ test, $\left.p=0.001\right)$. The association between knowledge and practice and other variables was statistically insignificant (Table 1).

\section{Discussion}

There were more female than male HCPs in the study population, and more nurses than other HCPs participated in the study. This is similar to the population composition of HCPs in studies undertaken in other countries. ${ }^{[1]}$

When the percentage of HCPs who reported having inadequate knowledge of waste disposal practices was added to the percentage of those who were not sure about the adequacy of their knowledge,
Table 1. Sociodemographic variables in relation to knowledge and practice regarding disposal of medical waste among HCPs $(N=178)$

\begin{tabular}{lll}
\hline Variable & $\boldsymbol{n}(\%)$ & $\boldsymbol{p}$-value \\
\hline Gender & \\
Male & $34(19.1)$ & \\
Female & $144(80.9)$
\end{tabular}

Professional category

Doctor $9(5.1)$

Dentist $3(1.7)$

Nurse $150(84.3)$

Allied health worker $\quad 16(9.0)$

Knowledge of HCPs

Inadequate knowledge $\quad 80(44.9)$

Not sure $14(7.9)$

Adequate knowledge $\quad 84(47.2)$

Practice of HCPs

Correct practice $\quad 110(61.8)$

Not sure $11(6.2)$

Incorrect practice $\quad 57(32.0)$

Gender and knowledge regarding correct $\quad 0.243$

disposal of medical waste

Males

$\begin{array}{ll}\text { Inadequate knowledge } & 15(8.4) \\ \text { Not sure } & 5(2.8) \\ \text { Adequate knowledge } & 14(7.9)\end{array}$

Adequate knowledge

Females

Inadequate knowledge $\quad 65(36.5)$

Not sure $9(5.1)$

Adequate knowledge $\quad 70(39.3)$

Gender and practice regarding disposal $\quad 0.908$

of medical waste

Males

Inadequate knowledge $10(5.6)$

Not sure $2(1.1)$

Adequate knowledge $22(12.4)$

Females

Inadequate knowledge $\quad 48(27.0)$

Not sure $8(4.5)$

Adequate knowledge $\quad 88(49.4)$

Age (years) and knowledge regarding 0.133 disposal of medical waste

$21-25$

Inadequate knowledge $\quad 4(2.2)$

Not sure $\quad 0(0.0)$

Adequate knowledge $\quad 0(0.0)$

$26-30$

Inadequate knowledge $8(4.5)$

Not sure $3(1.7)$

Adequate knowledge $\quad 8(4.5)$

Continued .. 
Table 1. (continued) Sociodemographic variables in relation to knowledge and practice regarding disposal of medical waste among HCPs $(N=178)$

\begin{tabular}{|c|c|c|}
\hline Variable & $n(\%)$ & $p$-value \\
\hline \multicolumn{3}{|l|}{$31-35$} \\
\hline Inadequate knowledge & $15(8.4)$ & \\
\hline Not sure & $0(0.0)$ & \\
\hline Adequate knowledge & $18(10.1)$ & \\
\hline \multicolumn{3}{|l|}{$>36$} \\
\hline Inadequate knowledge & $53(29.8)$ & \\
\hline Not sure & $11(6.2)$ & \\
\hline Adequate knowledge & $58(32.6)$ & \\
\hline $\begin{array}{l}\text { Age (years) and practice regarding disposal } \\
\text { of medical waste }\end{array}$ & & 0.139 \\
\hline \multicolumn{3}{|l|}{$21-25$} \\
\hline Incorrect practice & $4(2.2)$ & \\
\hline Not sure & $0(0.0)$ & \\
\hline Correct practice & $0(0.0)$ & \\
\hline \multicolumn{3}{|l|}{$26-30$} \\
\hline Incorrect practice & $8(4.5)$ & \\
\hline Not sure & $1(0.6)$ & \\
\hline Correct practice & $10(5.6)$ & \\
\hline \multicolumn{3}{|l|}{$31-35$} \\
\hline Incorrect practice & $10(5.6)$ & \\
\hline Not sure & $2(1.1)$ & \\
\hline Correct practice & $21(11.8)$ & \\
\hline \multicolumn{3}{|l|}{$>36$} \\
\hline Incorrect practice & $36(20.2)$ & \\
\hline Not sure & $7(3.9)$ & \\
\hline Correct practice & $79(44.4)$ & \\
\hline $\begin{array}{l}\text { Professional category and knowledge } \\
\text { regarding disposal of medical waste }\end{array}$ & & 0.003 \\
\hline \multicolumn{3}{|l|}{ Doctor } \\
\hline Inadequate knowledge & $7(3.9)$ & \\
\hline Not sure & $0(0.0)$ & \\
\hline Adequate knowledge & $2(1.1)$ & \\
\hline \multicolumn{3}{|l|}{ Dentist } \\
\hline Inadequate knowledge & $2(1.1)$ & \\
\hline Not sure & $1(0.6)$ & \\
\hline Adequate knowledge & $0(0.0)$ & \\
\hline \multicolumn{3}{|l|}{ Nurse } \\
\hline Inadequate knowledge & $58(32.6)$ & \\
\hline Not sure & $12(6.7)$ & \\
\hline Adequate knowledge & $80(44.9)$ & \\
\hline \multicolumn{3}{|l|}{ Allied health worker } \\
\hline Inadequate knowledge & $13(7.3)$ & \\
\hline Not sure & $1(0.6)$ & \\
\hline \multirow[t]{2}{*}{ Adequate knowledge } & $2(1.1)$ & \\
\hline & \multicolumn{2}{|c|}{ Continued ... } \\
\hline
\end{tabular}

the total percentage of HCPs who are assumed to have inadequate knowledge of correct waste disposal practices was higher than
Table 1. (continued) Sociodemographic variables in relation to knowledge and practice regarding disposal of medical waste among $\operatorname{HCPs}(N=178)$

\begin{tabular}{ll}
\hline Variable & $\boldsymbol{n}(\%)$ \\
\hline $\begin{array}{l}\text { Professional category and practice regarding } \\
\text { disposal of medical waste }\end{array}$ & \\
$\quad$ Doctor & \\
$\quad$ Incorrect practice & $5(2.8)$ \\
$\quad$ Not sure & $0(0.0)$ \\
$\quad$ Correct practice & $4(2.2)$
\end{tabular}

Dentist

$\begin{array}{ll}\text { Incorrect practice } & 1(0.6) \\ \text { Not sure } & 1(0.6) \\ \text { Correct practice } & 1(0.6)\end{array}$

Nurse

Incorrect practice

Not sure

Correct practice

$101(56.7)$

Allied health worker

$\begin{array}{ll}\text { Incorrect practice } & 12(6.7) \\ \text { Not sure } & 0(0.0) \\ \text { Correct practice } & 4(2.2)\end{array}$

Years of experience and knowledge about 0.506 disposal of medical waste

0 - 5

Inadequate knowledge

Not sure

Adequate knowledge

$6-10$

Inadequate knowledge

Not sure

Adequate knowledge

$11-15$

Inadequate knowledge

Not sure

Adequate knowledge

$$
16-20
$$

Inadequate knowledge

Not sure

Adequate knowledge

$>21$

Inadequate knowledge

Not sure

Adequate knowledge

$18(10.1)$

Continued ..

the percentage who reported having adequate knowledge of these practices. The low proportion who reported adequate knowledge of correct disposal practices is worrying, as lack of knowledge of correct disposal methods may lead to incorrect disposal of medical waste. Studies to evaluate training on medical waste disposal among HCPs have indicated that training improved knowledge of correct disposal practices. ${ }^{[12,13]}$ Incorrectly disposed medical 


\begin{tabular}{|c|c|c|}
\hline Variable & $n(\%)$ & $p$-value \\
\hline $\begin{array}{l}\text { Years of experience and practice regarding } \\
\text { disposal of medical waste }\end{array}$ & & 0.873 \\
\hline \multicolumn{3}{|l|}{$0-5$} \\
\hline Incorrect practice & $16(9.0)$ & \\
\hline Not sure & $1(0.6)$ & \\
\hline Correct practice & $26(14.6)$ & \\
\hline \multicolumn{3}{|l|}{$6-10$} \\
\hline Incorrect practice & $11(6.2)$ & \\
\hline Not sure & $1(0.6)$ & \\
\hline Correct practice & $25(14.0)$ & \\
\hline \multicolumn{3}{|l|}{$11-15$} \\
\hline Incorrect practice & $9(5.1)$ & \\
\hline Not sure & $3(1.7)$ & \\
\hline Correct practice & $18(10.1)$ & \\
\hline \multicolumn{3}{|l|}{$16-20$} \\
\hline Incorrect practice & $7(3.9)$ & \\
\hline Not sure & $2(1.1)$ & \\
\hline Correct practice & $16(9.0)$ & \\
\hline \multicolumn{3}{|l|}{$>21$} \\
\hline Incorrect practice & $15(8.4)$ & \\
\hline Not sure & $3(1.7)$ & \\
\hline Correct practice & $25(14.0)$ & \\
\hline
\end{tabular}

Table 2. Association between knowledge and practice regarding disposal of medical waste

\begin{tabular}{lllll}
\hline & $\begin{array}{l}\text { Inadequate } \\
\text { practice, } \\
\boldsymbol{n}(\%)\end{array}$ & $\begin{array}{l}\text { Not sure, } \\
\boldsymbol{n}(\%)\end{array}$ & $\begin{array}{l}\text { Correct } \\
\text { practice, } \\
\boldsymbol{n}(\%)\end{array}$ & $\boldsymbol{p}$-value \\
\hline $\begin{array}{l}\text { Inadequate } \\
\text { knowledge, } n(\%)\end{array}$ & $40(22.5)$ & $5(2.8)$ & $35(19.7)$ & 0.000 \\
$\begin{array}{l}\text { Not sure, } n(\%) \\
\text { Adequate }\end{array}$ & $2(1.1)$ & $1(0.6)$ & $11(6.2)$ & \\
knowledge, $n(\%)$ & $16(9.0)$ & $4(2.2)$ & $64(36.0)$ & \\
& & & &
\end{tabular}

waste is a hazard to healthcare workers, patients, visitors and the environment. ${ }^{[1,2,8,9]}$ The results of this study are similar to the results of studies conducted in other countries and reveal a lack of adequate knowledge and awareness of medical waste disposal among HCPs. ${ }^{[11]}$ The results further show that a small proportion of HCPs were not sure of the adequacy of their knowledge of waste disposal techniques despite having been taught the correct techniques as part of their professional education and training, but continued to generate and dispose of medical waste in their day-to-day activities. It is expected that HCPs will possess the necessary knowledge to dispose of medical waste correctly. ${ }^{[5]}$

The proportion of HCPs who reported that they disposed of medical waste correctly was higher than the proportion who did not. The results are similar to those of a 2008 SA study ${ }^{[6]}$ and a 2013 Indian study, ${ }^{[11]}$ which showed that doctors and nurses disposed of medical waste correctly. A study conducted in Ethiopia found that only $35.0 \%$ of HCPs disposed of medical waste correctly. ${ }^{[14]}$ Another
SA study conducted in the Free State Province ${ }^{[15]}$ found that $79 \%$ of HCPs disposed of medical waste incorrectly. The difference between the findings of this study and our study is huge, but the Free State study was conducted in all public hospitals in the province whereas ours was conducted in only one hospital.

The majority of HCPs at the hospital had adequate knowledge regarding disposal of medical waste and disposed of medical waste correctly. A small number were unsure about their knowledge and practices with respect to the disposal of medical waste. There was no association between knowledge and practice of waste disposal among HCPs and age, gender and years of experience, but there was an association between professional category and knowledge and practice of medical waste disposal.

\section{Study limitations}

Informal language was used in some of the questions in the questionnaire, and this could have caused information bias, as respondents had varying levels of understanding of English. Some of the questions were phrased in a manner biased towards the expected answer.

\section{Conclusions}

The results show that there is insufficient knowledge of disposal of medical waste among HCPs. Correct medical waste disposal practices were practised by more than half of the HCPs. Nurses comprised the highest proportion of professionals undertaking proper practices. This implies that there is a need to train other professional categories to ensure correct disposal of medical waste. The findings show that there was no association between knowledge and practice of waste disposal and age, gender or years of experience. There was an association between professional category and knowledge and practice of waste disposal, and also an association between actual practice of waste disposal and knowledge of the correct disposal techniques. Disposal of medical waste is the responsibility of all HCPs, and they are required to have knowledge of disposal techniques and to implement waste management guidelines. There is a need to improve the knowledge of HCPs with regard to waste disposal, particularly among doctors, allied health staff and dentists, as their practice scores were lower than those of nurses. This will further increase compliance with the correct disposal of medical waste.

\section{Recommendations}

It is recommended that hospital management explore the feasibility of training and supervision of all HCPs on the disposal of medical waste, considering available resources. Lack of resources, insufficient supervision and poor training were identified as causes of incorrect disposal of medical waste by HCPs. ${ }^{[1]}$

Babanyara YY, Ibrahim DB, Garba T, Bogoro AG, Abubakar MY. Poor medical waste management (MWM) practices and its risks to human health and the environment: A literature review. Int J Environ Health Sci Eng 2013;7(11): 780-787.

2. World Health Organization. Safe Management of Wastes from Health-care Activities. Geneva: WHO, 2014. http://www.who.int/water_sanitation_health/medicalwaste/wastemanag/en/ (accessed 15 February 2016).

. Nemathaga F, Maringa S, Chimuka L. Hospital solid waste management practices in Limpopo Province, Nemathaga F, Maringa S, Chimuka L. Hospital solid waste management practices in Limpopo Province,
South Africa: A case study of two hospitals. Waste Manag 2008;28(7):1236-1245. DOI:10.1016/j. wasman.2007.03.033

4. Health Professions Council of South Africa. Guidelines for the Management of Health Care Waste. Pretoria: HPCSA, 2008.

Republic of South Africa. Occupational Health and Safety Act 85 of 1993. Pretoria: Government Printer, 1993.

6. Republic of South Africa. National Environmental Management Waste Act 59 of 2008. Cape Town: Government Printer, 2008.

Ramokate T, Basu D. Health care waste management at an academic hospital: Knowledge and practices of doctors and nurses. S Afr Med J 2009;99(6):444- 445.

8. Sharma A, Sharma V, Sharma S, Singh P. Awareness of biomedical waste management among health care personnel in Jaipur, India. Oral Health Dent Manage 2013;12(1):32-40. DOI:10.4172/22472452.1000487

9. Ream PSF, Tipple AFV, Salgado TA, Souza SMB, Galdino-Júnior H, Alves SB. Hospital housekeepers: Victims of ineffective hospital waste management. Arch Environ Occup Health 2016;71(5):273-280. DOI:10.1080/19338244.2015.1089827 
10. Al-Emad AA. Assessment of medical waste management in the main hospitals in Yemen. East Mediterr Health J 2011;17(10):730-737.

World Health Organization. Spotlight on Statistics: A Fact File on Health Workforce Statistics. Geneva: WHO, 2008. http://www.who.int/hrh/statistics/spotlight/en/ (accessed 10 February 2016).

12. Nagaraju B, Padmavathi GV, Puranik DS, Shantharaj MP, Sampulatha SP. A study to assess the knowledge and practice on biomedical waste management among the health care providers working in PHCs of Bagepalli Taluk with the view to prepare informational booklet. Int J Med Biomed Res 2013;2(1):28-35. DOI:10.14194/ijmbr.216

13. Sapkota B, Gupta GK, Mainali D. Impact of intervention on healthcare waste management practices in a tertiary care governmental hospital of Nepal. BMC Public Health 2014;14:1005. DOI:10.1186/14712458-14-100
14. Ozder A, Teker B, Eker HH, Altindis S, Kocaakman M, Karabay O. Medical waste management training for healthcare managers - a necessity? J Environ Health Sci Eng 2013;11:20. DOI:10.1186/2052$336 \mathrm{X}-11-20$

15. Mahasa PS, Ruhiiga TM. Medical waste management practices in north eastern Free State, South Africa. J Hum Ecol 2014;48(3):439-450.

\section{Appendix 1. Questionnaire}

\section{Section A: Demographic information}

1. Gender

\begin{tabular}{|l|l|l|l|}
\hline Male & 1 & Female & 2 \\
\hline
\end{tabular}

2. Age, years

\begin{tabular}{|l|l|l|l|l|l|l|l|}
\hline $21-25$ & 1 & $26-30$ & 2 & $31-35$ & 3 & $>35$ & 4 \\
\hline
\end{tabular}

3. Professional category

\begin{tabular}{|l|l|l|l|l|l|l|l|}
\hline Doctor & 1 & Dentist & 2 & Nurse & 3 & Allied health (specify) & 4 \\
\hline
\end{tabular}

4. Years of experience

\begin{tabular}{|l|l|l|l|l|l|l|l|l|l|}
\hline $0-5$ & 1 & $6-10$ & 2 & $11-15$ & 3 & $16-20$ & 4 & $>20$ & 5 \\
\hline
\end{tabular}

\section{Section B: Knowledge}

\begin{tabular}{|l|l|l|l|l|}
\hline & Statement & Disagree & Agree & Neutral \\
\hline 5 & $\begin{array}{l}\text { I know from policy that personal protective } \\
\text { equipment is to be used routinely when } \\
\text { handling medical waste. }\end{array}$ & 1 & $\mathbf{0}$ \\
\hline 6 & $\begin{array}{l}\text { I am aware of the regulation that placing } \\
\text { medical waste in wrong bin is a high risk. }\end{array}$ & 1 & 2 & 0 \\
\hline 7 & $\begin{array}{l}\text { I am aware that there are waste bins for } \\
\text { disposal of wastes as regulated }\end{array}$ & 1 & 2 & 0 \\
\hline 8 & $\begin{array}{l}\text { I know of policy documents regarding adequate } \\
\text { disposal procedures of human tissue remains. }\end{array}$ & 1 & 2 & 0 \\
\hline 9 & $\begin{array}{l}\text { I read and understood that throwing human } \\
\text { tissue remains in domestic waste is an adequate } \\
\text { disposal procedure. }\end{array}$ & 1 & 2 & 0 \\
\hline 10 & $\begin{array}{l}\text { I read and understood that throwing expired } \\
\text { blood units in domestic waste is an adequate } \\
\text { disposal procedure. }\end{array}$ & 1 & 2 & 0 \\
\hline
\end{tabular}




\begin{tabular}{|c|c|c|c|c|}
\hline 11 & $\begin{array}{l}\text { I know from policy documents that it is } \\
\text { necessary to sort medical waste at the point of } \\
\text { generation. }\end{array}$ & 1 & 2 & 0 \\
\hline 12 & $\begin{array}{l}\text { Our policy document dictates that liquid waste } \\
\text { must be disposed into the sewage without } \\
\text { processing or treatment. }\end{array}$ & 1 & 2 & 0 \\
\hline 13 & $\begin{array}{l}\text { I consider used dressings, cotton and plasters as } \\
\text { medical waste according medical waste } \\
\text { classification. }\end{array}$ & 1 & 2 & 0 \\
\hline 14 & $\begin{array}{l}\text { I know that used cartons, paper and plastics are } \\
\text { classified as medical waste }\end{array}$ & 1 & 2 & 0 \\
\hline 15 & $\begin{array}{l}\text { I am aware that improper waste disposal can } \\
\text { lead to needlestick injuries. }\end{array}$ & 1 & 2 & 0 \\
\hline 16 & $\begin{array}{l}\text { Our policy document informs us that the } \\
\text { colour code for disposal of human, biological } \\
\text { and any object that has been in contact with } \\
\text { body fluids is yellow, as per guidelines for waste } \\
\text { management. }\end{array}$ & 1 & 2 & 0 \\
\hline 17 & $\begin{array}{l}\text { I know that the colour code for microbiological } \\
\text { waste is red, as per guidelines for waste } \\
\text { management. }\end{array}$ & 1 & 2 & 0 \\
\hline 18 & $\begin{array}{l}\text { I am aware that untreated medical waste can be } \\
\text { stored for more than } 48 \text { hours in the temporary } \\
\text { storage area, as per regulations. }\end{array}$ & 1 & 2 & 0 \\
\hline 19 & $\begin{array}{l}\text { I know from policy documents that any waste } \\
\text { mixed with medical waste must be treated as } \\
\text { medical waste. }\end{array}$ & 1 & 2 & 0 \\
\hline 20 & $\begin{array}{l}\text { I read and understood that improper waste } \\
\text { disposal may lead to transmission of diseases. }\end{array}$ & 1 & 2 & 0 \\
\hline
\end{tabular}

Section C: Practice

\begin{tabular}{|l|l|l|l|l|}
\hline & Statement & $\begin{array}{l}\text { Disagree } \\
\mathbf{2}\end{array}$ & $\begin{array}{l}\text { Agree } \\
\mathbf{2}\end{array}$ & $\begin{array}{l}\text { Neutral } \\
=\mathbf{0}\end{array}$ \\
\hline 21 & Gloves used when handling medical waste. & 1 & 2 & 0 \\
\hline
\end{tabular}




\begin{tabular}{|c|c|c|c|c|}
\hline 22 & $\begin{array}{l}\text { Colour coding used for segregating medical } \\
\text { waste. }\end{array}$ & 1 & 2 & 0 \\
\hline 23 & Medical waste separated from general waste. & 1 & 2 & 0 \\
\hline 24 & $\begin{array}{l}\text { Medical waste segregated into infectious and } \\
\text { non-infectious waste. }\end{array}$ & 1 & 2 & 0 \\
\hline 25 & $\begin{array}{l}\text { Special plastic bags used once for collecting } \\
\text { medical waste. }\end{array}$ & 1 & 2 & 0 \\
\hline 26 & $\begin{array}{l}\text { Liquid waste disposed in bags that prevent } \\
\text { leakage. }\end{array}$ & 1 & 2 & 0 \\
\hline 27 & $\begin{array}{l}\text { Blood waste disposed in separate bags that } \\
\text { prevent leakage. }\end{array}$ & 1 & 2 & 0 \\
\hline 28 & $\begin{array}{l}\text { Human tissue remains disposed in separate } \\
\text { bags that prevent leakage. }\end{array}$ & 1 & 2 & 0 \\
\hline 29 & $\begin{array}{l}\text { Liquid wastes collected together with other } \\
\text { wastes. }\end{array}$ & 1 & 2 & 0 \\
\hline 30 & $\begin{array}{l}\text { Liquid waste disposed directly into sewage } \\
\text { system without any processing (dilution } \\
\text { and/or sterilisation). }\end{array}$ & 1 & 2 & 0 \\
\hline 31 & $\begin{array}{l}\text { Liquid waste disposed into sewage system } \\
\text { after processing. }\end{array}$ & 1 & 2 & 0 \\
\hline 32 & Used needles not recapped. & 1 & 2 & 0 \\
\hline 33 & $\begin{array}{l}\text { Used needles discarded immediately after } \\
\text { use. }\end{array}$ & 1 & 2 & 0 \\
\hline 34 & $\begin{array}{l}\text { Used needles discarded in a designated } \\
\text { sharps container. }\end{array}$ & 1 & 2 & 0 \\
\hline 35 & $\begin{array}{l}\text { Sharps containers are replaced when they are } \\
3 / 4 \text { full. }\end{array}$ & 1 & 2 & 0 \\
\hline 36 & $\begin{array}{l}\text { Waste containers labelled with biohazard } \\
\text { stickers. }\end{array}$ & 1 & 2 & 0 \\
\hline 37 & $\begin{array}{l}\text { Needlestick injury reported to the } \\
\text { occupational health nurse. }\end{array}$ & 1 & 2 & 0 \\
\hline 38 & $\begin{array}{l}\text { A temporary waste storage area available in } \\
\text { the hospital. }\end{array}$ & 1 & 2 & 0 \\
\hline 39 & Personal protective equipment available. & 1 & 2 & 0 \\
\hline 40 & $\begin{array}{l}\text { Waste monitoring inspections conducted on } \\
\text { monthly basis. }\end{array}$ & 1 & 2 & 0 \\
\hline
\end{tabular}

